\title{
PENGARUH APLIKASI PUPUK SILIKA DALAM PENGENDALIAN TUNGRO
}

\section{THE EFFECT OF SILICA FERTILIZER APPLICATION IN TUNGRO CONTROL}

\author{
Khaerana1a, A Gunawan' ${ }^{1}$ \\ ${ }^{1}$ Loka Penelitian Penyakit Tungro, Indonesia. \\ a Korespondensi: Khaerana, E-mail: khaerana.hafid@yahoo.com \\ (Diterima: 15-12-2018; Ditelaah: 16-12-2018; Disetujui: 04-01-2019)
}

\begin{abstract}
Tungro is one of the important rice diseases, caused by two types of virus, namely Rice Tungro Bacilliform Virus (RTBV) and Rice Tungro Spherical Virus (RTSV), through the vector of green leafhoppers (Nephotetic virescens). The high plantation intensity causes the balance of nutrients decreases, including the element of silica. Proper application of silica fertilizers can improve soil fertility and cause plants to be more resistant to pests. The purpose of this study was to examine the effect of silica fertilizer application in tungro disease control. The study used two factor factorial design. The first factor is the dose of silica fertilizer (control, NPK dose commonly used by farmers, $1 / 3 \mathrm{NPK}+1$ lt Si, $1 / 3 \mathrm{NPK}+3$ lt Si, $1 / 3 \mathrm{NPK}+5$ lt Si), , the second factor is the use of varieties (Inpari 36 and TN1). The results showed that the interaction of dosage of silica fertilizer and varieties had no significant effect on all observation parameters except in grain yield. Varieties have significant effect on plant height, panicle length, and grain yield.
\end{abstract}

Keywords : Green leafhopper, silica fertilizer, tungro.

\begin{abstract}
ABSTRAK
Tungro adalah salah satu penyakit penting pada padi, yang disebabkan oleh dua jenis virus, yaitu Rice Tungro Bacilliform Virus (RTBV) dan Rice Tungro Spherical Virus (RTSV), melalui vektor wereng hijau (Nephotetic virescens). Tingginya intensitas pertanaman menyebabkan keseimbangan unsur hara semakin berkurang, termasuk unsur silika (Si). Pemberian pupuk silika dengan dosis yang tepat dapat meningkatkan kesuburan tanah dan menyebabkan tanaman lebih tahan terhadap serangan hama penyakit. Tujuan penelitian ini untuk mengkaji pengaruh pemberian pupuk silika dalam pengendalian penyakit tungro. Penelitian menggunakan rancangan faktorial dua faktor. faktor pertama yaitu dosis pemberian pupuk silika (kontrol, NPK dosis umum digunakan petani, 1/3 NPK + 1 lt si, 1/3 NPK + 3 lt si, 1/3 NPK + 5 lt si), faktor kedua adalah penggunaaan varietas (inpari 36 dan TN1). Hasil penelitian menunjukkan bahwa interaksi pemberian dosis pupuk silika dan varietas tidak berpengaruh nyata terhadap semua parameter pengamatan, kecuali pada hasil gabah. Varietas berpengaruh nyata terhadap tinggi tanaman, panjang malai, dan hasil gabah.
\end{abstract}

Kata Kunci: Pupuk silika, tungro, wereng hijau.

Khaerana., \& Gunawan, A. (2019). Pengaruh Aplikasi Pupuk Silika Dalam Pengendalian Tungro . Jurnal Pertanian, 10(1), 1-7. 


\section{PENDAHULUAN}

Tingginya intensitas pertanaman menyebabkan terjadinya degradasi kesuburan tanah. Tanah menjadi kekurangan unsur hara dan tanaman menjadi rentan terserang hama dan penyakit. Penyakit tungro merupakan penyebab turunnya produksi gabah di Indonesia. Berdasarkan data BBPOPT Jatisari 2016, luas lahan yang terserang tungro mencapai 1.055 ha.

Tungro adalah penyakit yang disebabkan oleh virus RTBV (Rice Tungro Bacilliform Virus) dan RTSV (Rice Tungro Spherical Virus). Kedua jenis virus tersebut ditularkan oleh wereng hijau (Nephotetic virescens) secara semipersisten (Hibino et al., 1990). RTBV bergantung pada RTSV untuk ditularkan oleh wereng hijau (Hibino and Cabauatan, 1987). Gejala penyakit tungro pada padi dikenali dengan ciri utama yaitu perubahan warna daun menjadi kuning, anakan yang berkurang, tanaman kerdil, pemunculan malai tertahan, gabah kecoklatan karena pengisian tidak sempurna (Ling,1972 dalam Arfianis, 2006; (Faizal and Fauziah, 2010). Dewasa ini ada tiga komponen utama pengendalian tungro, yaitu penggunaan varietas tahan dan tanam serempak, eradikasi sumber inoculum, dan keputusan dalam pemilihan varietas dan pengaturan waktu tanam (Praptana et al., 2013)

Silika (Si) merupakan salah satu unsur kimia kedua terbanyak dikerak bumi (lithosphere) yaitu $27,6 \%$ dan diserap hampir semua tanaman dalam bentuk asam monoksilat (monosilicic acid) atau $\mathrm{Si}(\mathrm{OH})_{4}$ (Makarim et al., 2007), namun semakin intensifnya pertanaman menyebabkan keberadaannya semakin menipis. Hal ini semakin diperparah dengan ikut terangkutnya jerami dan sekam yang merupakan sumber $\mathrm{Si}$ organik. Apabila kondisi ini terjadi dalam jangka panjang, maka akan menurunkan produktivitas tanaman serta kemampuan tanaman bertahan terhadap bermacam gangguan cekaman maupun serangan hama penyakit (Husnain et al., 2011), seperti penggerek batang kuning (Nakata et al., 2008), wereng coklat, wereng hijau, dan hama punggung putih (Ma dan Takahashi 2002 dalam Makarim et al., 2007).

(Laing, 2006) menemukan bahwa pada kadar silikon yanag tinggi, sangat sedikit nimpa wereng coklat menjadi dewasa, dan penurunan usia wereng coklat dewasa serta terjadi penurunan tingkat kesuburan wereng coklat betina. Pemberian silika dapat memperbaiki fungsi fisiologi tanaman, meningkatkan jumlah anakan maksimum (Yohana et al., 2013) meningkatkan hasil panen dan bahan biomassa tanaman (Voleti et al., 2008). Lapisan silika juga akan menyebabkan tanaman lebih tahan terhadap serangan penyakit. Kekurangan unsur hara Si pada areal persawahan menjadi salah satu penyebab rendahnya produktivas tanaman padi dewasa ini. Namun penelitian terdahulu, sepanjang penulis ketahui masih jarang yang meneliti pengaruh Si terhadap daya tahan padi terhadap hama penyakit tungro. Penelitian ini bertujuan untuk mengkaji pengaruh pemberian pupuk silika dalam pengendalian penyakit tungro.

\section{MATERI DAN METODE}

Penelitian ini dilaksanakan di kebun percobaan Loka Penelitian Penyakit Tungro. Penelitian menggunakan Rancangan Faktorial Dua Faktor dalam RAK (Rancangan Acak Kelompok). Faktor pertama adalah dosis pupuk, yaitu: Kontrol = L1 (tanpa perlakuan), L2 (NPK, sesuai dengan dosis dan metode yang umum digunakan oleh petani, yaitu urea $300 \mathrm{~kg} / \mathrm{ha}$, phonska $300 \mathrm{~kg} / \mathrm{ha}$ ), L3(1/3 dosis NPK + Si 1 lt/ha), L4(1/3 dosis NPK + Si 3 lt/ha), L5 (1/3 dosis NPK + Si 5 lt/ha). Faktor kedua adalah varietas, yaitu: Taichun Native 1 atau TN1 (varietas peka), dan Inpari 9 (varietas yang tahan tungro). Komposisi unsur hara yang terkandung di dalam pupuk majemuk yang digunakan, dapat dilihat pada Tabel 1 . Setiap unit perlakuan berukuran $3 \mathrm{~m}$ x $4 \mathrm{~m}$, dan setiap perlakuan diulang sebanyak 3 kali, sehingga terdapat 30 unit percobaan.

Tabel 1. Kompusisi Unsur Hara Pupuk Majemuk yang digunakan pada penelitian aplikasi pupuk silika dalam pengendalian tungro.

\begin{tabular}{llc}
\hline No. & Unsur & Jumlah \\
\hline 1. & $\mathrm{Si}$ & $0,8-1,2 \%$ \\
2. & $\mathrm{P}_{2} \mathrm{O}_{5}$ & $0,02-0,05 \%$ \\
3. & $\mathrm{Ca}$ & $0,07-0,08 \%$ \\
4. & $\mathrm{S}$ & $0,02-0,03 \%$ \\
5. & $\mathrm{Mn}$ & $8-12 \mathrm{mg} / \mathrm{L}$ \\
6. & $\mathrm{Cu}$ & $0,5-1,0 \mathrm{mg} / \mathrm{L}$ \\
7. & $\mathrm{Mo}$ & $<0,01 \mathrm{mg} / \mathrm{L}$ \\
8. & $\mathrm{N}$ & $60-80 \mathrm{mg} / \mathrm{L}$ \\
9. & $\mathrm{K} 2 \mathrm{O}$ & $0,05-0,1 \%$ \\
10. & $\mathrm{Mg}$ & $0,05-0,1 \%$
\end{tabular}




$$
\begin{array}{clc}
\text { 11. } & \text { Fe } & 40-60 \mathrm{mg} / \mathrm{L} \\
\text { 12. } & \mathrm{Zn} & 25-30 \mathrm{mg} / \mathrm{L} \\
\text { 13. } & \mathrm{B} & 0,01-0,04 \\
& & \mathrm{mg} / \mathrm{L}
\end{array}
$$

Sumber : Label Produk Pupuk (2016)

\section{Pelaksanaan Penelitian}

Persemaian dilakukan di luar petak penelitian. Bibit padi yang telah berumur kurang lebih 21 hari dipindah tanam pada setiap petak penelitian dengan sistem tanam jajar legowo 4:1, dengan 1 bibit perlubang tanam. Pada perlakuan yang menggunakan pupuk Si, aplikasi pupuk urea dan NPK phonska dilakukan hanya sekali pada umur 7 HST (Hari Setelah Tanam) dengan dosis $1 / 3$ dari dosis yang umum digunakan, dilanjutkan dengan aplikasi pupuk Si pada umur 2, 4, 6, dan 8

\begin{tabular}{|c|c|c|}
\hline $\begin{array}{l}\text { Parameter } \\
\text { Pengamatan }\end{array}$ & Pelaksanaan & Waktu \\
\hline Tinggi Tanaman & $\begin{array}{l}\text { Diukur dari permukaan tanah sampai sampai ujung } \\
\text { daun tertinggi }\end{array}$ & menjelang panen \\
\hline Jumlah anakan & Dihitung jumlah anakan yang terbentuk & Menjelang panen \\
\hline Jumlah malai & Menghitung jumlah malai pada 3 rumpun sampel & Menjelang panen \\
\hline Hasil gabah & $\begin{array}{l}\text { Ditimbang, kemudian dikonversi dalam kg/Ha pada } \\
\text { Kadar Air (KA) } 14 \%\end{array}$ & Setelah panen \\
\hline $\begin{array}{l}\text { Gabah hampa per } \\
\text { malai }\end{array}$ & $\begin{array}{l}\text { Menghitung jumlah gabah hampa dari } 3 \text { rumpun } \\
\text { sampel }\end{array}$ & Setelah panen \\
\hline Gabah isi/ malai & Menghitung gabah isi dari 3 rumpun sampel & Setelah panen \\
\hline Berat 1000 butir & Menimbang gabah 1000 butir, KA 14\%, & Setelah panen \\
\hline Panjang malai & Diukur dari leher sampai ujung malai & Setelah panen \\
\hline $\begin{array}{l}\text { Populasi Wereng } \\
\text { hijau }\end{array}$ & $\begin{array}{l}\text { Dilakukan menggunakan sweepnet, diayunkan } \\
\text { sebanyak } 10 \text { ayunan ganda, secara diagonal pada plot } \\
\text { pengamatan }\end{array}$ & $\begin{array}{l}2, \quad 4, \quad 6, \quad 8 \text { Minggu } \\
\text { Setelah Tanam (MST) }\end{array}$ \\
\hline Tungro & $\begin{array}{l}\text { Secara visual, melihat ciri tanaman terserang tungro } \\
\text { (daun kuning oranye, batang memendek, jumlah } \\
\text { anakan berkuranh) }\end{array}$ & $2,4,6,8 \mathrm{MST}$ \\
\hline Skor Kerebahan & Skor 1= Baik; 3=agak rebah; 5=rebah & Menjelang Panen \\
\hline
\end{tabular}
MST. Parameter pengamatan dapat dilihat pada Tabel 2.

Tabel 2. Parameter Pengamatan

Data yang diperoleh diuji dengan menggunakan uji $F$, dan jika berbeda nyata akan dilanjutkan dengan uji Tukey (Gomez and Gomez, 1995). Data diolah menggunakan software minitab 16.

\section{HASIL DAN PEMBAHASAN}

Hasil analisis sidik ragam pengaruh kombinasi perlakuan varietas dan pupuk silika (Si) terhadap berbagai parameter yang diamati dapat dilihat pada Tabel 3.

Tabel 3. Rekapitulasi Sidik Ragam Pengaruh Kombinasi Perlakuan Varietas Dan Pupuk Silika Terhadap Berbagai Peubah Pengamatan.

\begin{tabular}{lccc}
\hline Parameter & Varietas & Pupuk & Interaksi \\
\hline Tinggi tanaman & $S$ & $N S$ & $N S$ \\
Jumlah malai & $N S$ & $N S$ & $N S$ \\
Panjang malai & $S$ & $N S$ & $N S$ \\
Jumlah anakan & $N S$ & $N S$ & $N S$ \\
Skor kerebahan & $N S$ & $N S$ & $N S$ \\
Gabah isi/malai & $N S$ & $N S$ & $N S$
\end{tabular}


Gabah hampa/malai

Berat 1000 biji KA $14 \%$
NS

NS
NS

$N S$
NS

NS

$S$

$N S$

NS

Jumlah wereng

NS

NS

Huruf superscript yang berbeda dibelakang angka pada baris yang sama menunjukkan adanya perbedaan nyata pada taraf uji Tukey $5 \%$. Tabel 4 menunjukkan bahwa parameter tinggi tanaman, panjang malai, dan hasil gabah berbeda nyata pada perlakuan varietas. Terlihat bahwa varietas inpari 9 menunjukkan hasil yang lebih baik dibandingkan TN1. Keunggulan yang diperlihatkan oleh inpari 9 tidak terlepas dari faktor genetik varietas tersebut. (Gardner et al. 1991) menyatakan bahwa tinggi rendahnya pertumbuhan dan hasil tanaman sangat dipengaruhi oleh dua faktor, yaitu faktor internal dan faktor eksternal. Faktor internal merupakan faktor yang dipengaruhi oleh sifat genetik atau sifat turunan seperti umur tanaman, morfologi tanaman, daya hasil, kapasitas menyimpan cadangan makanan, ketahanan terhadap penyakit, dan lain-lain. Faktor eksternal merupakan faktor lingkungan, seperti iklim, tanah, dan faktor biotik. Perbedaan pertumbuhan yang diperoleh dipengaruhi oleh satu faktor atau lebih.

\begin{tabular}{lcc}
\hline Parameter & Varietas TN 1 & $\begin{array}{c}\text { Varietas } \\
\text { Inp. } 9\end{array}$ \\
\hline Tinggi & $51,4^{\mathrm{b}}$ & $53,6^{\mathrm{a}}$ \\
Tanaman & & \\
$\begin{array}{l}\text { Panjang } \\
\text { Malai }\end{array}$ & $23,3^{\mathrm{b}}$ & $24,0^{\mathrm{a}}$ \\
Hasil & $2167,0^{\mathrm{b}}$ & $3604,4^{\mathrm{a}}$ \\
\hline
\end{tabular}

Tabel 5. Rata-Rata Jumlah Anakan, Jumlah Malai (Helai), Gabah Isi/Malai (g), Gabah Hampa/Malai (g), Bobot 1000 Biji KA 14\% (g), Skor Kerebahan, Serangan Tungro (\%), Wereng Hijau (Ekor) Pada Perlakuan Varietas Dan Dosis Pupuk Si.

\begin{tabular}{lcccccccc}
\hline Perlakuan & $\mathrm{Ju}$ & Jumlah & Gabah & Gabah & Berat & Skor & tungro & Wereng \\
& mla & malai & isi & Hampa & 1000 & kerebahan & hijau \\
\hline Varietas: & & & & & & &
\end{tabular}

$\begin{array}{lrrrrrrrr}\text { TN1 } & 7,9 & 7,5 & 106,9 & 17,1 & 11,9 & 1,5 & 1,6 & 4,0 \\ \text { Inp } 9 & 8,7 & 7,8 & 116,9 & 18,2 & 11,8 & 1,9 & 1,0 & 4,3\end{array}$

Dosis:

Kontrol

$7,9 \quad 9,1 \quad 109,9$

11,8

11,7

1,7

0,6 


$\begin{array}{lrrrrrrrr}\text { NPK } & 8,2 & 7,3 & 112,7 & 25,6 & 12,1 & 2,3 & 2,4 & 3,9 \\ \text { 1/3NPK+ Si 1 lt Si } & 8,7 & 7,1 & 112,4 & 14,0 & 11,9 & 1,3 & 1,4 & 4,1 \\ & & & & & & & & \\ \text { 1/3NPK+3 lt Si } & 8,2 & 8,3 & 120,0 & 22,9 & 11,9 & 2,0 & 1,2 & 4,1 \\ \text { 1/3NPK+5 lt Si } & 8,8 & 6,4 & 104,3 & 13,8 & 11,7 & 1,3 & 0,9 & 4,7\end{array}$

Tabel 5 menunjukkan bahwa interaksi antara perlakuan varietas dan dosis pupuk tidak berpengaruh nyata terhadap parameter jumlah anakan, jumlah malai, gabah isi, gabah hampa, berat 1000 biji, skor kerebahan, serangan tungro, dan jumlah wereng hijau yang diperoleh pada populasi tanaman. Parameter-parameter tersebut juga tidak menunjukkan hasil yang berbeda nyata untuk masing-masing faktor tunggal (varietas maupun maupun dosis pupuk).

Hasil yang diperoleh adalah varietas inpari 9 lebih tinggi pada jumlah malai, jumlah anakan, gabah isi, dan jumlah wereng hijau, dibanding varietas TN 1. Sedangkan varietas TN 1 lebih tinggi pada parameter berat 1000 biji, dan jumlah serangan tungro. Tabel ini menunjukkan bahwa meskipun jumlah wereng hijau yang terdapat pada populasi varietas inpari 9 lebih banyak, namun jumlah serangan tungro pada varietas inpari 9 lebih kecil dibanding varietas TN 1. Hal ini berarti bahwa preferensi wereng hijau terhadap suatu varietas, tidak berbanding lurus dengan serangan tungro. Rendahnya tingkat serangan penyakit tungro pada inpari 9, karena varietas ini merupakan varietas yang dirakit untuk tahan virus tungro. Sesuai dengan pendapat (Wahab et al., 2017), yang menyatakan bahwa Inpari 9 merupakan hasil varietas unggul baru padi spesifik lokasi, dimana memiliki keunggulan tahan terhadap penyakit tungro, dan memiliki potensi hasil 9,3 t/ha GKG.

Skor kerebahan pada inpari 9 lebih tinggi dibanding varietas TN1, hal ini kemungkinan disebabkan karena inpari 9 memiliki tinggi tanaman lebih tinggi dibanding TN 1. (Yamin and Moentono, 2005) menyatakan bahwa indeks kerebahan sangat berkaitan dengan tinggi tanaman. Tinggi tanaman yang sedang paling sesuai dan cenderung lebih tahan rebah dibanding tanaman yang lebih tinggi. Menurut (Silitonga et al., 2003) kerebahan pada tanaman padi ditunjukkan dengan skala skor 1-3. Skor 1 menunjukkan tanaman tidak rebah, skor 2 menunjukkan tanaman agak rebah 2, dan skor 3 menunjukkan tanaman rebah (Silitonga et al., 2003). Fakta ini menunjukkan bahwa perakitan varietas unggul, tidak mampu menjawab semua kendala di lapangan, baik faktor biotik maupun abiotik. Sehingga penggunaan suatu varietas, haruslah berbasis pemecahan masalah yang bersifat spesifik lokasi.

Pemberian dosis pupuk 1/3 NPK +5 liter $\mathrm{Si}$ menunjukkan hasil terbaik pada parameter jumlah anakan, sesuai hasil penelitian (Yohana et al., 2013) dan skor kerebahan, masing-masing 8,8 anakan dan 1,3. Pupuk Si mampu menginisiasi penambahan jumlah anakan pada tanaman padi, namun tidak berkorelasi positif terhadap jumlah malai, gabah isi dan berat 1000 biji. Jadi, meskipun pemberian pupuk dapat meningkatkan jumlah anakan, namun anakan yang terbentuk bukan anakan yang produktif, karena tidak mampu menginisiasi munculnya malai pada tiap anakan, dan juga berpengaruh pada pengisian gabah, sehingga diperoleh banyak gabah hampa. Kemungkinan hal ini disebabkan oleh terkurasnya hasil metabolit pada tanaman untuk menyokong pertumbuhan anakan, sehingga source (organ tanaman yang berperan aktif melakukan proses fotosintesis) tidak seimbang dengan sink (bulir padi) yang terbentuk. Menurut (Makarim dan Suhartatik, 2009), hasil gabah terkait dengan agihan bahan kering atau efisiensi fotosintesis. Oleh karena itu tingginya produksi biomassa tidak menggambarkan tingginya hasil gabah.

Perlakuan pupuk NPK Pada pemupukan NPK dengan dosis yang umum dipakai oleh petani setempat, menunjukkan hasil berat 1000 biji tertinggi, jumlah gabah hampa tertinggi, skor kerebahan tertinggi, dan jumlah serangan tungro tertinggi, masing-masing pada angka 12,1 gr; 2,3 ; dan 2,4 tanaman. Hal ini menunjukkan bahwa pemberian pupuk NPK dalam jumlah yang banyak dapat meningkatkan berat 1000 biji gabah, namun juga memiliki sisi negatif, yaitu dapat membuat tanaman lebih mudah rebah. Hal ini kemungkinan disebabkan tingginya dosis penggunaan pupuk $\mathrm{N}$, dimana pupuk $\mathrm{N}$ berperan terhadap aktivitas fotosintesis (Yoshida, 1981) yang menyebabkan meningkatnya biomassa tanaman, namun jika dosis yang digunakan berlebih, dapat membuat tanaman menjadi sukulen. Tanaman sukulen akan memudahkan 
tanaman menjadi rebah dan juga cenderung disukai oleh serangga, termasuk wereng hijau.

Skor kerebahan terendah juga ditunjukan dengan pemberian $\mathrm{Si}$, hal ini sesuai dengan pernyataan (Setyorini and Abdulrachman, 2008) yang menyatakan bahwa dengan adanya Si pada sistem pertanaman padi, batang tanaman menjadi lebih kuat dan kekar sehingga tanaman tidak mudah rebah.

Tabel 6. Hasil Gabah Kering Giling (Kg/Ha) pada Interaksi antara Varietas dan Pupuk Silika.

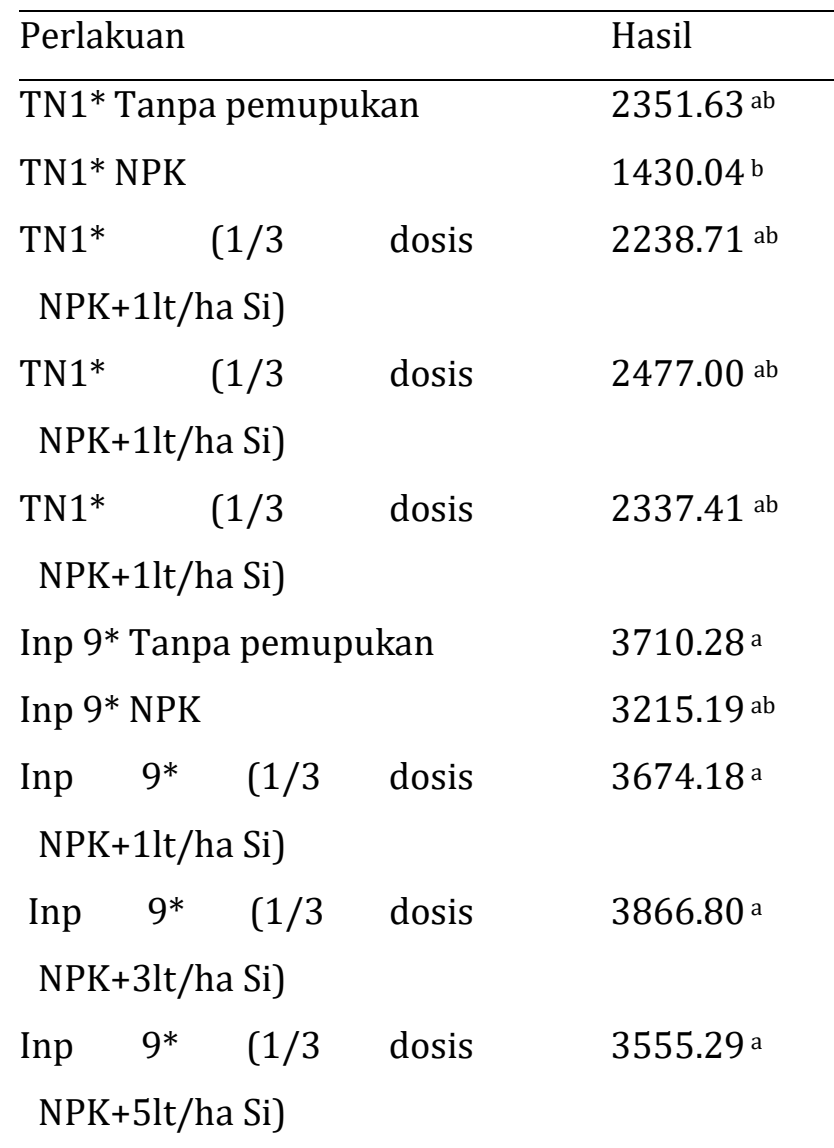

Huruf superscript yang berbeda dibelakang angka pada kolom yang sama menunjukkan adanya perbedaan nyata pada taraf uji Tukey $5 \%$. Interaksi antara dosis pupuk dan varietas berbeda nyata pada parameter hasil gabah kering giling (kg/ha). Varietas inpari 9 dengan dosis pemupukan $1 / 3$ dosis $\mathrm{NPK}+3$ lt pupuk cair $\mathrm{Si}$ menunjukkan hasil yang terbaik dibanding perlakuan lainnya yaitu $3866,80 \mathrm{~kg} / \mathrm{ha}$. Hal ini sesuai dengan hasil penelitian (Yohana et al., 2013); (Husnain et al., 2011); (Voleti et al., 2008) pada tanaman padi, dan (Kiswondo, 2011) pada tanaman tomat. Silikat diperlukan untuk menjadikan tanaman memiliki bentuk daun yang tegak (tidak terkulai), sehingga daun efektif menangkap radiasi surya dan efekif dalam penggunaan hara $\mathrm{N}$ yang menentukan tinggi atau rendahnya hasil tanaman (Makarim et al., 2007).

Pemupukan dengan dosis Si yang lebih tinggi, tidak menunjukkan hasil yang lebih baik hasil gabah kering gilingnya. Ini berarti bahwa pupuk Si kemungkinan telah mencapai titik kulminasi dalam hal peningkatan hasil gabah pada tanaman padi. Pemberian pupuk Si lebih dari dosis tersebut, hanya akan menyebabkan pengeluaran biaya, tanpa diikuti oleh peningkatan hasil tanaman.

\section{KESIMPULAN}

Terjadinya degradasi unsur Si pada lahan sawah salah satu penyebabnya adalah ikut terangkutnya sisa panen dari areal pertanaman, sehingga tanaman padi tidak tahan terhadap cekaman biotik maupun abiotik. Penggunaan pupuk Si pada padi, menyebabkan tanaman padi memiliki permukaan daun yang tebal dan batang yang kokoh, sehingga tidak mudah terserang hama penyakit.

Tungro merupakan penyakit pada padi, yang disebabkan oleh virus dan ditularkan melalui wereng hijau. Aplikasi pupuk Si pada varietas TN1 dan varietas inpari 9 tidak berpengaruh nyata pada penurunan tingkat serangan tungro, namun berpengaruh nyata meningkatkan gabah kering giling tanaman padi. Penggunaan pupuk Si belum dapat direkomendasikan untuk mengatasi masalah penyakit tungro sampai diperoleh dosis dan teknologi yang tepat.

\section{DAFTAR PUSTAKA}

Arfianis (2006) Diferensiasi Empat Isolat Rice Tungro Bacilliform Badnavirus dengan PCRRFLP. Institut Pertanian Bogor.

Faizal and Ladja Fauziah T (2010) 'Tungro: Permasalahan dan Strategi Pengendalian', in Prosiding Seminar Ilmiah dan Pertemuan Tahunan PBJ Dan PFJ XX Komisariat Daerah Sulawesi Selatan, pp. 114-117.

Gomez, K. A. and Gomez, A. A. (1995) Prosedur Statistik untuk Penelitian Pertanian, UI Press. Edited by Sjamsudin E and J. SB. Jakarta. doi: $10.2174 / 156802611796235107$.

Hibino, H.. (1990) 'Resistance in Rice to Tungro Associated Viruses', Plant Disease, 74(11), pp. 923-926.

Hibino, H. and Cabauatan, P. Q. (1987) 'Infectivity Neutralization of Rice Tungro-Associated 
Viruses Acquired by Vector Leafhoppers', Phytopathology, 77(3), pp. 473-476.

Husnain, Rochayati, S. and Adamy, I. (2011) 'Pengelolaan Hara Silika pada Tanah Pertanian di Indonesia', Balai Litbang Pertanian, 10, pp. 237-246. Available at: http://balittanah.litbang.pertanian.go.id/ind/ dokumentasi/lainnya/21- Husnain et al. Pengelolaan Hara Silika pada Tanah Pertanian di Indonesia.pdf.

Kiswondo, S. (2011) 'Penggunaan Abu Sekam dan Pupuk ZA terhadap Pertumbuhan dan Hasil Tanaman Tomat (Lycopersicum esculentum Mill.)', Jurnal Embryo, 8(1), pp. 9-17.

Makarim, A. K. and Suhartatik, E. (2009) Morfologi dan Fisiologi Tanaman Padi. Sukabumi, Subang.

Makarim, A. K., Suhartatik, E. and Kartohardjono, A. (2007) 'Silikon: Hara Penting pada Sistem Produksi Padi', Iptek Tanaman Pangan, 2(2), pp. 195-204.

Nakata, Y.. (2008) 'Rice blast disease and susceptibility to pests in a silicon uptakedeficient mutant lsi1 of rice', Crop Protection, 27, pp. 865-868. doi: 10.1016/j.cropro.2007.08.016.

Praptana, R. H. et al. (2013) 'Patogenisitas Virus Tungro pada Varietas Tetua Padi Tahan Tungro', Fitopatologi Indonesia, 9(6), pp. 186192. doi: 10.14692/jfi.9.6.186.

Setyorini, D. and Abdulrachman, S. (2008) 'Pengelolaan Hara Mineral Tanamana Padi'.
Bogor: Badan Penelitian dan Pengembangan Pertanian, pp. 109-148.

Silitonga, T. S.. (2003) Panduan Sistem Karakterisasi dan Evaluasi Tanaman Padi. Edited by S. Moeljopawiro, B. Suprihatno, and I. N. Orbani. Bogor: Badan Penelitian dan Pengembangan Pertanian Komisi Nasional Plasma Nutfah.

Voleti, S. R.. (2008) 'Effect of silicon solubilizers on silica transportation, induced pest and disease resistance in rice ( Oryza sativa L .)', Crop Protection, 27, pp. 1398-1402. doi: 10.1016/j.cropro.2008.05.009.

Wahab, M. I. et al. (2017) Deskripsi Varietas Unggul Baru Padi. Sukamandi: Badan Penelitian dan Pengembangan Pertanian Kementerian Pertanian.

Yamin, M. and Moentono, M. D. (2005) 'Seleksi Beberapa Varietas Padi untuk Kuat Batang dan Ketahanan Rebah Tinggi', Ilmu Pertanian, 12(2), pp. 94-102.

Yohana, O., Hanum, H. and Supriadi (2013) 'Pemberian Bahan Silika pada Tanah Sawah Berkadar P Total Tinggi untuk Memperbaiki Ketersediaan P dan Si Tanah, Pertumbuhan dan Produksi Padi (Oryza sativa L.)', Jurnal Online Agroekoteknologi, 1(4), pp. 1444-1452.

Yoshida, S. (1981) Fundamentals of Rice Crop Science. Philippines: International Rice Research Institute. 